\title{
P-T evolution across the Main Central Thrust zone (Eastern Nepal): hidden discontinuities revealed by petrology
}

\author{
Chiara Groppo ${ }^{1 *}$, Franco Rolfo ${ }^{1,2}$ and Bruno Lombardo 2 \\ 1 Dipartimento di Scienze Mineralogiche e Petrologiche, University of Torino, ITALY \\ 2 Istituto di Geoscienze e Georisorse, CNR - Section of Torino, ITALY \\ *For correspondence, email: chiara.groppo@unito.it; franco.rolfo@unito.it
}

Identifying the location and nature of the Main Central Thrust Zone (MCTZ) is a major challenge in most of the Himalayan chain. As a contribution to clarifying this geopuzzle, a number of metapelite samples were selected for petrologic studies along a transect on the eastern flank of the "Arun Tectonic Window" (Bordet 1961) in eastern Nepal. The results provide information on the distribution of the Lesser Himalaya and MCTZ in a relatively poorly known area.

Both to the west and east of the study area, the classical Makalu and Kangchendzonga transects (Brunel and Kienast 1986, Lombardo et al. 1993, Meier and Hiltner 1993, Pognante and Benna 1993, Goscombe and Hand 2000, Goscombe et al. 2006) show metamorphic units characterized by a well-documented inverted metamorphism, with a general increase of metamorphic grade northward from lower (Lesser Himalaya) to higher (Higher Himalaya Crystallines - HHC) structural levels across the MCTZ (e.g. Le Fort 1975, Arita 1983, Valdiya 1983, Hodges et al. 1998, Inger and Harris 1992, Vannay and Hodges 1996).

Metamorphic assemblages in the studied metapelites range fromthelow-gradechloritezone $(\mathrm{Chl}+\mathrm{Wm}+\mathrm{Qtz}+\mathrm{Pl} \pm \mathrm{Ctd} \pm \mathrm{Mn}$ rich Grt), to the medium-grade staurolite $(\mathrm{Wm}+\mathrm{Bt}+\mathrm{Grt}+\mathrm{St})$ and kyanite $(\mathrm{Wm}+\mathrm{Bt}+\mathrm{Grt}+\mathrm{St}+\mathrm{Ky})$ zones, up to the sillimanite zone $(\mathrm{Wm}+\mathrm{Bt}+\mathrm{Grt}+\mathrm{Sil}+\mathrm{Pl} \pm \mathrm{St} \pm \mathrm{Ky})$ and a further zone of partial melting with the appearance of K-feldspar and the breakdown of white mica. The P-T evolution of 5 metapelite samples collected at different structural levels has been reconstructed in detail using the modern petrological approach of P-T pseudosections, and considering the possible chemical fractionation of the bulk rock composition due to the presence of zoned porphyroblasts (e.g., garnet).

The resulting P-T paths may be grouped in three different families:

(i) the structurally lower Lesser Himalayan samples show a prograde $\mathrm{P}-\mathrm{T}$ path characterized by an increase in both $\mathrm{P}$ and $\mathrm{T}$, up to peak metamorphic conditions of $550^{\circ} \mathrm{C}$ and $0.65 \mathrm{GPa}$;

(ii) two structurally intermediate samples preserve relics of a prograde history characterized by heating and decompression from $550^{\circ} \mathrm{C}, 1.0 \mathrm{GPa}$ to $620^{\circ} \mathrm{C}, 0.8 \mathrm{GPa}$ and from $570^{\circ} \mathrm{C}, 1.1 \mathrm{GPa}$ to $650^{\circ} \mathrm{C}, 0.9 \mathrm{GPa}$, respectively, showing a similar exhumation history characterized by cooling and decompression along the same metamorphic gradient;

(iii) the structurally higher samples consist of mostly unzoned minerals and well equilibrated assemblages that do not preserve relics of their prograde metamorphic history. Peak metamorphic $\mathrm{T}$ and $\mathrm{P}$ of these two samples are higher than the structurally lower MCTZ samples: $650^{\circ} \mathrm{C}, 0.7 \mathrm{GPa}$, but still inside the white mica stability field, and $\sim 780^{\circ} \mathrm{C}, 1.0 \mathrm{GPa}$, beyond the stability limit of white mica and in the melt-bearing field.

The different P-T paths inferred for the studied metapelites suggest the presence of important metamorphic discontinuities that are not structurally evident in the field because the regional metamorphic fabric mainly developed during late deformation events. The first discontinuity found may correspond to the MCT in the classical sense of Heim and Gansser (1939) as it juxtaposes the medium-grade metamorphic units of the MCTZ, characterized by a clockwise P-T path with heating during decompression followed by cooling and decompression, over the Lesser Himalaya sequence, which only preserves prograde metamorphism characterised by an increase in both $\mathrm{P}$ and $\mathrm{T}$. A second discontinuity, at a higher structural level, separates units of the MCTZ from overlying metapelites that were metamorphosed at higher $\mathrm{T}$ and relatively lower $\mathrm{P}$.

\section{References}

Arita K. 1983. Origin of the inverted metamorphism of the Lower Himalayas, Central Nepal. Tectonophysics 93: 43-60

Bordet P. 1961. Recherches géologiques dans l'Himalaya du Népal, région du Makalu. Paris: Editions du Centre National de la Recherche Scientifique. 275 p

Brunel M and JR Kienast. 1986. Etude pétro-structurale des chevauchements ductiles himalayens sur la transversale de l'Everest-Makalu (Népal oriental). Canadian Journal of Earth Sciences 23: 1117-1137

Goscombe B and M Hand. 2000. Contrasting P-T paths in the Eastern Himalaya, Nepal: inverted isograds in a paired metamorphic mountain belt. Journal of Petrology 41: 1673-1719

Goscombe B, D Gray and M Hand. 2006. Crustal architecture of the Himalayan metamorphic front in eastern Nepal. Gondwana Research 10: 232-255

Heim A and A Gansser. 1939. Central Himalaya: geological observations of the Swiss expedition 1936. Memoir Society Helvetica Science Nature 73: 1-245

Hodges KV, S Bowring, K Davidek, D Hawkins and M Krol. 1998. Evidence for rapid displacement on Himalayan normal faults and the importance of tectonic denudation in the evolution of mountain ranges. Geology 26: 483- 486

Inger S and NBW Harris. 1992. Tectonothermal evolution of the High Himalaya: geochemical and sedimentological evidence. Geology 10: 439-452

Le Fort P. 1975. Himalayas: the collided range. Present knowledge of the continental arc. American Journal of Science 275: 1-44

Lombardo B, P Pertusati and A Borghi. 1993. Geology and tectono-magmatic evolution of the eastern Himalaya along the Chomolungma-Makalu transect. Geological Society of London, Special Publication 74: 341-355

Meier K and E Hiltner. 1993. Deformation and metamorphism within the Main Central Thrust zone, Arun tectonic Window, eastern Nepal. Geological Society of London, Special Publication 74: 511-523

Pognante U and P Benna. 1993. Metamorphic zonation, migmatization, and leucogranites along the Everest transect (Eastern Nepal and Tibet): record of an exhumation history. Geological Society of London, Special Publication 74: 323-340

Valdiya KS. 1983. Tectonic setting of Himalayan granites. In: Shams FA (ed), Granites of Himalayas Karakorum and Hindu Kush, Lahore Punjab University, 39-53

Vannay JC and KV Hodges. 1996. Tectonometamorphic evolution of the Himalayan metamorphic core between the Annapurna and Dhaulagiri, central Nepal. Journal of Metamorphic Geology 14: 635-656 